\title{
CORRECTION
}

\section{Correction to: Mothers' knowledge and attitudes about newborn screening in Jordan}

\author{
Abedallah Kasem ${ }^{1} \cdot$ Nadin M. Abdel Razeq ${ }^{2} \cdot$ Sawsan Abuhammad ${ }^{1} \cdot$ Haneen Alkhazali $^{1}$ \\ Published online: 19 February 2022 \\ ○) Springer-Verlag GmbH Germany, part of Springer Nature 2022
}

\section{Correction to: Journal of Community Genetics} https://doi.org/10.1007/s12687-021-00572-x

The original version of this article unfortunately contained a mistake.

Affiliation 2 should read as below:

School of Nursing, Maternal and Child Health Nursing

Department, the University of Jordan, Amman, 11942, Jordan

Furthermore, all authors agree to change the corresponding author from "Nadin M. Abdel Razeq" to "Abedallah Kasem".

This is being corrected in this publication.

Publisher's note Springer Nature remains neutral with regard to jurisdictional claims in published maps and institutional affiliations.

The original article can be found online at https://doi.org/10.1007/ s12687-021-00572-x.

Abedallah Kasem

aykasem@just.edu.jo

1 Faculty of Nursing, Maternal and Child Health Nursing Department, Jordan University of Science and Technology (JUST), P.O. Box (3030), Irbid 22110, Jordan

2 School of Nursing, Maternal Child Health Nursing Department, the University of Jordan, Amman 11942, Jordan 